\title{
THE VARIETIES OF SICK EXPERIENCE: NIETZSCHE, JAMES, AND THE ART OF HEALTH
}

Jason M. Wirth*

\begin{abstract}
RESUMO - O artigo propõe um diálogo entre William James e Friedrich Nietzsche acerca da natureza da doença e sua superação ou convalescença. À primeira vista, seria uma tolice reconciliar o renascimento religioso com a convalescença que levou Nietzsche à "grande saúde." A fim de tentar ir além desta insensatez, consideraremos cuidadosamente o locus onde a saúde emerge para ambos pensadores. A discussão é motivada, ademais, por um interesse no destino da religião após a morte de Deus.
\end{abstract}

PALAVRAS-CHAVE - Convalescença. Deus. Doença. Experiência religiosa. Saúde.

\begin{abstract}
The essay seeks to bring William James into dialogue with Friedrich Nietzsche around the issue of the nature of sickness, and its overcoming or convalescence. It is, at first glance, folly to reconcile religious rebirth with the convalescence that led Nietzsche to the "great health." To try and see beyond this folly, we will consider carefully the site in which health emerges for both thinkers. This discussion is further motivated by an interest in the prospects for religion after the death of God.
\end{abstract}

KEY WORDS - Convalescence. God. Health. Religious experience. Sickness.

For my friend, Dawn Cho

\section{Sick of it all}

In his profound study of religion, The Varieties of Religious Experience (1902), William James distinguishes two antinomian types of human experience: healthy-mindedness and the sick soul. The former demanded a habitual and disciplined denial of evil, abjection, and horror in favor of a uniformly positive disposition towards life. One becomes "feelingless to evil" and in "these states, the ordinary contrast of good and ill seems to be swallowed up in a higher denomination, an omnipotent excitement which engulfs the evil, and which the human being welcomes as the crowning experience of his life."1 The enthusiastic disposition that feels that everything is good, that, in a sense, there is only good, has been the ambition of much of the American talking cure, therapeutic optimism, and even indicated a fundamental mood of attunement, according to James, for someone like Walt Whitman. Depression, sadness, self-destructive rages in the pit of nihilism, and wilting despairs are signs of a bad attitude and an immature and feckless perspective. As soon as

Associate Professor, Dept. of Philosophy, Seattle University.

William James, The Varieties of Religious Experience (New York: Modern Library, 2002), 103. Henceforth VR.

\begin{tabular}{|l|l|l|l|l|l|}
\hline VERITAS & Porto Alegre & v. 54 & n. 1 & jan./mar. 2009 & p. 101-112 \\
\hline
\end{tabular}


one thinks more positively about the world, the world somehow cooperates and appears more positive. Perhaps for the greatest practitioners of this overflowing positivity, the world is revealed to have been all along without evil and ugliness. Walt Whitman's majestic affirmation is, however, the exception that reminds us of the norm: that most all positive thinkers, like most all people, eventually hit a wall, namely, an experience of the abject that contests assimilation, that shatters the prophylactic of their healthy-mindedness. "But it breaks down impotently as soon as melancholy comes; and even though one be quite free from melancholy one's self, there is no doubt that healthymindedness is inadequate as a philosophical doctrine, because the evil facts which it refuses positively to account for are a genuine portion of reality" (VR, 182).

In a sense, from a more contemporary perspective, one can now more clearly discern that the movement that begin with American popular culture's incessant auto suggestion that everything is great, that positive thinking makes one more powerful by rendering illusory human life's unappetizing aspects, will culminate in a culture whose leader flaunts his "optimism" as if it were a sufficient condition to change the world and whose population trends towards self-medication as a condition for a properly functional and cheery life. Megalomaniacal optimism and the Prozac nation share the same root: the conflation of health with the inflation of idealism. By the latter I mean that the problem of health is understood to be in some fundamental sense an outgrowth, a symptom, of the quality of one's subjectivity. If the subject succeeds in believing her or his own dramatic declaration of optimism and by means of a willful fallacy of collection decides that the good parts of life speak to and for the whole of life, then the evaluative mode ceases to distinguish anything. One becomes insensate to sickness and evil, which evaporate into the bright day where everything is blindingly good.

But "living simply in the light of the good is splendid as long as it will work" (VR, 182). Should the blinding light fail to protect one from the experiences that rebel against the mood of omnibenevolence, then one must render the subject even more insensate. When autocratic moods and beliefs are not enough, when the mind cure no longer repels the barbarian forces of sickness, and optimism "breaks down impotently as soon as melancholy comes" (VR, 182), one must further blunt one's sensitivity, becoming "happier and healthier," with pain medication, non-prescribed narcotics, or massive, almost sublime, levels of denial. One medicates the pain that dis-eases the failing optimist, allowing life once again to appear palatable and "healthy." Mother's "little helper" (valium or whatever else is fashionable) succors mother's erupting despair by artificially elevating her subjective standpoint.

Former President George W. Bush, who, among many other debacles, some of which have not yet come to light, presided over a worldwide financial crisis, two failed wars, one of which was illegal and promoted on maliciously deceptive intelligence, the further destabilization of the Middle East, the ero- 
sion of the American justice system, the use of torture and extraordinary rendition, a stunning culture of corruption and cronyism, and immense environmental degradation, had a rug in front of his desk announcing that an optimistic person works here. He was fond of talking about this rug. Recounting how presidents are at some liberty to design parts of the Oval Office, Bush fondly recalled that, "The interesting thing about this rug and why I like it in here is "cause I told Laura one thing. I said, 'Look, I can't pick the colors and all that. But make it say 'optimistic person'." ${ }^{2}$ No matter how bad things were going, in New Orleans, in Baghdad, in the Justice Department, excessive emphasis on them was a symptom of pessimism, which presumably indicated weakness, an inability to lead. Pessimism was itself the malady, not the events that were making one pessimistic. Bush: the imperium of the once-born, and in this sense the sickness of a certain conception of health.

The implication is clear: the "once-born," that is, those who can affirm the whole of life naturally, are either exceedingly rare, natural born sages that humble us with their equanimity, or, as is usually the case, are hucksters, the desperate, global marketers who hide their crimes under the veneer of a chipper attitude, citizens of the New Age, and other dreamers, all of whom are likely headed for a rude awakening. Optimism is in this respect nascent sickness, waiting for the clarity of the dark night to flush it out.

The "twice-born" on the other hand emerge from the dark depths of life with an increased capacity to affirm the whole of experience. Religious experience increases one's capacity for life, but it does not do so through therapeutically playing the bait and switch of either medical idealism (the decision to see life as what it is not) or medical materialism (just medicate the brain into pleasure states). Or to put it more succinctly, religious experience, as opposed to the institutional forms of religion, is not something that I experience, but rather an experience that alters one's very sense of self, that suggests that the search for health in the narcissistic field of egoism is itself a symptom of the most pernicious and delusional kind of sickness: one that drives one to "cures" that appear as such because of the nature of the sickness. This sickness drives one to "cures" that are sometimes worse than the original sickness and in the best case scenario merely distract one from any clarity regarding the nature of one's sickness.

James famously defined religion as the "feelings, acts, and experiences of individual men in their solitude, so far as they apprehend themselves to stand in relation to whatever they may consider the divine" (VR, 36). The religion being analyzed is the experience of religion and not therefore the collective behavior of shared rituals, common dogmas, and mass movements. (James is still criticized by theologians and others for attempting to dispense with scrip-

Peter Baker, "Bush Weaves Rug Story Into Many an Occasion: President Uses His Oval Office Floor Covering as a Metaphor for Optimism and Leadership," The Washington Post, Tuesday, March 7, 2006, A15. 
ture, theology, and church tradition as starting points.) Nor is religion a merely personal matter, as if the subject were merely and perhaps mysteriously following individual preferences and more generally confusing their fancies with an experience of supreme value. Religion is first and foremost experienced in solitude (not in institutions, rituals, and collective movements) and in some way is even the experience of solitude itself. The latter should not be confused with a state of abandoned and forlorn individualism. ${ }^{3}$ The individual, when abandoned by others, or isolated by a repressive government, is left to themselves, and knows loneliness.

Hannah Arendt later and powerfully distinguished loneliness, the bane of life in totalitarian states, from solitude: in the latter, "I am 'by myself,' together with myself, and therefore two-in-one, whereas in loneliness I am actually one, deserted by all others." "When, starving, I ask for food, it is as if I am speaking a language that no one understands. This is an example of the immense loneliness of contemporary global culture. Solitude, on the other hand, is always plural, in so far as I am not one, even to myself. This is not to say that every time I walk down a country path contemplating my past mistakes that I am necessarily having an experience of religious solitude. The latter is a deepening and radicalizing of solitude. Individualism, on the other hand, is the permanent risk of loneliness, or perhaps one might even infer that the loneliness and the quiet sadness of self-interested individuals who come together

\footnotetext{
This distinction calls for further clarification. In Memories and Studies, James argues that "Surely the individual, the person singular in number, is the more fundamental phenomenon, and the social institution, of whatever grade, is but secondary and ministerial" [(New York: Longmans, 1911), 102]. This "person, singular in number" has as its primary force the desire to reclaim the singularity of the person from its social determinations, from the dimension, perhaps, that Heidegger in 1927 designated das Man. Does that mean that the "person singular in number" reduces to the self-same ego, to the primary fact of a self-contained entity? This overstates the case. Individuality is to some extent that which resists subsumption into the abstract and general. When James insists that we respect the solitude of individual experience, he is preserving the domain of human experience that cannot be dictated from above by the general programs of institutions or even ideas. James Pawelski, in his recent study of the problem, The Dynamic Individualism of William James, develops the complex and intertwining evolution of the facets of this problem. He concludes: "Integrated as James individualism becomes, though, it remains radical. That is, it reaches to all dimensions of his discussion of the self. It is at work in on the social level in his argument that geniuses arise from a cycle of operation different from their environment and in his (qualified) defense of every individual's freedom of belief; it is apparent in his psychology in his claim that psychology is properly the study of the finite, individual minds and in his claim that every thought tends to be part of a particular personal consciousness; and it is expressed metaphysically in his preference for personal, private religion and his argument that individual human selves are constitutive of the divine consciousness." [Albany: State University of New York Press, 2007), 160]. Pawelski concludes that James' conception of individualism is even more radical than Kierkegaard's: "Kierkegaard's individual, who is derived from God, is less radical than James's individual, who is constitutive of God" (160). I still think that it is fair to say that although the problematic of individualism (= solitude) may be more fully articulated in thinkers like Nietzsche and Arendt, it is fully present in James' thought, although sometimes in a partially nascent form.

Hannah Arendt, The Origins of Totalitarianism (1951) (San Diego and New York: Harcourt, 1994), 477.
} 
with others simply because they share something of interest in common is a symptom of the sick soul who finds her or himself fundamentally forsaken.

Perhaps in solitude one still knows something of the sadness of things, but in loneliness, in being forsaken and abandoned to individuality, optimism is the mere postponement of melancholy. As Tolstoy lamented, "Why should I live? Why should I do anything? Is there in life any purpose which the inevitable death which awaits me does not undo and destroy? (VR, 173). Tolstoy's depression already articulated the nihilistic despair, the sense that one has been forsaken by life, abandoned to the loneliness and absurdity that death at first seems to promise. For Tolstoy, at least in the stage of the loneliness of being forsaken to the "meaningless absurdity of life" (VR, 174) this was akin to what Nietzsche diagnosed as the sickness of modernity: the reactive nihilism of das Umsonst! - of the sense that human striving is an exercise in futility. What was the death of God for Nietzsche if not the immense and aggressive loneliness of modernity? For Tolstoy, "it was like a feeling of dread that made me seem like an orphan and isolated in the midst of all these things that were so foreign" (VR, 174). This for James indicated "the core of the religious problem: Help! help!" (VR, 181). We have been forsaken! We are alone. When James recovered from his own severe bout of depression, one can wonder if this was an awakening from forlorn "individualism" to solitude. When James insists that he is a "rabid individualist," he is defending a specific kind of individualism, far from the rugged individualism of the capitalist consumers and corporate climbers, who are always in it for themselves, so to speak. He was defending the solitude of individualism, the solitude of the conversion of the forsaken self away from its obsession with itself and towards the radically other.

Into this forlorn sickness of the soul, solitude speaks to "a second birth, a deeper kind of conscious being" than one "could enjoy before" (VR, 175). For in this experience of solitude I am not only related to others, per haps even to all beings, but more fundamentally I find myself standing in relation to the divine, to a two-in-one that takes me beyond myself. In the second birth, the "regenerative change" (VR, 560) of the sick soul, the forsaken ones are taken beyond themselves, drawn to a non sequitur that could never have been derived from their affliction. "So long as the egoistic worry of the sick soul guards the door, the expansive confidence of the soul of faith gains no presence. But let the former faint away, even for a moment, and the latter can profit by the opportunity, and, having once acquired possession, may retain it" (VR, 235).

It is as if the sick soul experienced Arjuna's melancholic delirium in the Bhagavad-Gita, a text already known in the West by this time. Arjuna is unable to act, to get up and blow the conch shell. Krishna breaks through, draw-

Quoted in Pawelski, xiii. 
ing Arjuna away from himself, back to the life that he had long ago lost when he imagined that he was in charge of his life, standing in front of it, posed before it. The Gita calls this ahamkara, the illusion that "I act." In James' account of the second birth, or in the Gita's account of Arjuna's reclamation of his dharma, religion, to be related to that which is otherwise than oneself, is the experience of solitude, of a conversion to the non-sequitur of what is wholly otherwise.

Nonetheless, James' circumscription does not eschew all talk of individuality. One stands in relation to "whatever they may consider the divine," which risks sounding like the claim that religion originates in the sphere of subjectivity. What is religion to me? Indeed, James later confesses that to some extent religion is "essentially private and individualistic; it always exceeds our powers of formulation" (VR, 469). This is not to say, however, that in the end James collapses back into the lonely egoism of personal religious preferences. Here the language of individualism speaks to the depth of experience itself. It is not that the religious object is determined to have originated within the sphere of subjectivity, but rather that it takes the subject beyond her or himself in such a way that they can no longer speak precisely and universally to the nature of the experience that shattered the very frame of consciousness that characterized the sick soul. "Feeling is private and dumb, and unable to give an account of itself" (VR, 471). Individual religious experience here is much closer to Kierkegaard's knight of faith and the teleological suspension of the universality that comprises the ethical. ${ }^{6}$

And hence for James mystical experience, of interest to those who are already so inclined, has no power to demand assent outside of the solitude in which it was born, for "mystics have no right to claim that we ought to accept the deliverance of their peculiar experiences, if we are ourselves outsiders and feel no private call thereto" (VR, 462). There is no unanimity in the description of mystical experience, nor is there any way in which to evaluate good ecstatic experiences from diabolical ones, and, finally, such experiences do not readily yield the privacy of their solitude to the public life of reason and philosophical accounting. In this sense, the experience of religious solitude, to anticipate our discussion of Nietzsche, is for everyone and no one.

Yet this is in a sense a way of understanding the challenge that always confronts philosophy, namely to "redeem religion from unwholesome privacy" (VR, 471) and find the language to communicate this solitude, without collapsing in "an absolutely worthless invention of the scholarly mind" (VR, 487) like the excesses of Scholasticism. This may in some ways be an "absolutely hopeless (VR, 496) task, for, quite simply, "there is always a plus, a thisness, which feeling alone can answer for" (VR, 495). This surplus which disrupts the sick

As noted, Pawelski finds James' individualism more radical than that of Kierkegaard. Whether or not that is the case, the pertinence of Kierkegaard's analysis of the problem of the singularity of self-hood invites the comparison. 
soul, this electric shock of the plus that draws one back to a life that enchants us from its abeyance, is the return, the rebirth, of health, and health itself does not deliver itself to the alleged security of universals and other false, albeit institutionally enshrined, gods. What is it to us that the sick soul is well again? It is the gift of solitude, and therefore the gift of health, sundered from the medical gaze and its bag of "healthy" functions and indicators. In this sense, health is an art, not a medical science - an art born of the experience of solitude.

In this sense, as scandalous as it may first sound, there is a touch of Bataille's radical religiosity in James, for the former claimed that religion was erotic and "eroticism is silence . . . it is solitude. But not to the people whose very presence in the world is a pure negation of silence, idle chatter, a forgetfulness of the possibility of solitude." ${ }^{77}$ And in writing about Nietzsche's tonic of solitude, Bataille once asked, "Is there a silence more stifling, more soundproof, further beneath the earth?"8

\section{Dangerously healthy}

Perhaps a hasty reading of Nietzsche would locate him among the mysteriously healthy-minded, those so naturally beyond good and evil that they are beyond evaluation as such. Nietzsche would simply be that aberrant product of nature that readily and enthusiastically celebrates life in toto, and we would enviously stand on the sidelines, wishing for such a miracle in our own lives. I think that this would not only be a misguided reading, but it would be a symptom of the very sickness that Nietzsche diagnosed.

In the second aphorism of the second (1887) edition of The Gay Science, Nietzsche asks pointedly, "What is it to us that Herr Nietzsche has again become healthy?" ${ }^{9}$ Herr Nietzsche has convalesced and this, he claims, is of vital importance for us all. But what was this sickness and what is this health, and how does it speak to us, perhaps to those who first know themselves as us in terms of some collective individuality?

In a letter to his mother, Nietzsche, with his failing digestive system, chronic headaches and nausea, increasing blindness, and impending madness, claimed that he was the only healthy person in Europe. Indeed, the first aphorism of The Gay Science announces an effusive gratitude for an unexpected convalescence [Genesung] and indeed speaks of the Trunkenheit der Gene-

Georges Bataille, L'Erotisme (Paris: Les Éditions de Minuit, 1957), 292. Erotism: Death and Sensuality (1957), trans. Mary Dalwood (San Francisco: City Lights Books, 1986), 264.

8 Georges Bataille, Inner Experience, trans. Leslie Anne Boldt (Albany: State University of New York Press, 1988), 156.

9 Die Fröhliche Wissenschaft in the Sämtliche Werke: Kritische Studienausgabe in 15 Einzelbänden, ed. Giorgio Colli and Mazzino Montinari, (Munich: Deutscher Taschenbuch Verlag and Berlin: Walter de Gruyter, 1988), volume 3, 347. Henceforth KSA, followed by volume number and page citation. Translations, except where otherwise noted, are my own responsibility. 
sung, the drunkenness of convalescence (KSA 3, 345). How are we to think a drunken recovery that has nothing in common with the desperate drinking that comprises our quotidian benders? Towards the end of the Gay Science, Nietzsche speaks of this rebirth as the Great Health [die große Gesundheit]. It was the symptom of "the new ones, the nameless ones":

And now, after we have long been on our way in this manner, we Argonauts of the ideal, with more daring perhaps than is prudent, and have suffered shipwreck and damage often enough, but we are, healthier than one likes to permit us, dangerously healthy, ever again healthy. (KSA 3, 636).

Before the convalescence, Nietzsche had been exclusively sick. He had never in any way been healthy, and hence it would have been false to assume that his former sickness was a deviation from an allegedly normal state of health. He had to convalesce from a sickness that had never tasted health. Now Nietzsche, who, with his pain ridden body and looming insanity would never have been deemed healthy by the medical gaze, was healthy even in his sickness. His health was not the absence of sickness but rather a health beyond the duality of health and sickness, a great health, a kind of Übergesundheit, a trans-healthiness that governs the manner in which one is sick and healthy. Such a health is not found. It is not the result of jogging and tofu. It is unleashed. "This art of transfiguration is precisely philosophy" (KSA 3, 349). Thinking itself has been reborn, dares to affirm, after many centuries of sickness, a great health. This health has nothing to do with arriving at some culminating end state of being, in which the thinker and philosophy themselves get to be all they can be. One is always ever again healthy, on the way to the overflow of life that is the eternal return of the great health. In this sense, the Great Health is also an increase-even a maximization-of the capacity for life.

\section{Philosophy as Heilmittel}

Perhaps one might still protest that bringing Nietzsche into dialogue with James seems inessential, perhaps eccentric. Certainly Nietzsche was no friend of the herd mentality ("Platonism for the people") that congeals into religious fervor, famously arguing:

From the beginning there is something unhealthy in such priestly aristocracies and in the habits ruling there ... Habits that have as a consequence the intestinal disease and neurasthenia that almost unavoidably clings to the priests of all ages; but what they themselves invented as a medicine [Heilmittel] against this diseasedness of theirs-must we not say that in the end that it has proved itself a hundred times more dangerous in its aftereffects than the disease from which it was to redeem them? (KSA 5, 265/GM, 15)

The practice of religion involves running to a medicine-the promise of religious salvation-that in its very appearance as a Heilmittel indicates a) just how sick one really must have been for such a thing ever to have appeared 
either holy or healing; and b) that the diseases will further rage, albeit invisibly, as one runs towards sickness as if it were health. The more one tries to cure oneself, the sicker one becomes. Finally, disdaining all healthy air as if it bore pestilence, the sick soul gets right with God, and becomes virtuous:

The diseased softening and moralization by virtue of which the creature 'human' finally learns to be ashamed of all of his instincts. Along the way to 'angel' . . . the human has bred for themselves that upset stomach and coated tongue through which not only have the joy and the innocence of the animal become repulsive but life itself has become unsavory" (KSA 5, 302-303/GM, 43). ${ }^{10}$

James for his part refers to Nietzsche's critique of the saintly as "sickly enough" (VR, 407), but asking great thinkers to understand each other in order to remain great thinkers is symptom of the sick soul. For both, the health, the great health of solitude, involves the radical conversion to the plus that turns one away from oneself and towards the healing holiness of life, a turning that Nietzsche himself called das heilige Jasagen, the holy affirmation.

Furthermore, both thinkers share lineages that intersected with each other in surprising and remarkable ways. James was, for example, directly in the lineage of thought that included his Harvard predecessor Emerson, a thinker whom Nietzsche greatly admired. Furthermore, religious experience for James methodologically suspends any consideration of doctrinal or institutional commitments (always good sources for pestilence), and argues for a sense of religion with which we still have not fully come to terms. Religious experience is first and foremost experience, not ritual, doctrines, theology, institutions, or a philosophy. Experience, feeling, sensation, are all issues with which we are still grappling philosophically, precisely because they bring philosophy beyond its penchant demonstrations and unambiguous formulations. Religious experience does not, for example, only name a particular experience, but a variety of experiences, rendering "religion" itself a "collective name" (VR, 31). James carefully attempts not to lose this complexus of experiences in a hasty and false universal. Yet James, ever a good doctor and pragmatist, favors healthy experiences that are reborn from melancholy, a deep sickness in which life no longer draws us out of ourselves and which therefore "constitutes an essential moment in every complete religious evolution" (VR, 28). What is to us that I am healthy again?

Another figure, still today not fully appreciated, also participates in these intersecting lineages, namely Schelling. Although a thorough treatment of this kinship is best a topic for a further paper, I would to conclude with a couple of passing thoughts on this topic.

Karl Löwith was among the first to insist upon this kinship. "The utter lack of madness leads not to reason but to imbecility. The fundamental stuff of

I have used the following English translation of Zur Genealogie der Moral: On the Genealogy of Morality (1887), trans. Maudemarie Clark and Alan J. Swensen (Indianapolis: Hackett, 1998). 
all of life and existence is, according to Schelling as well as Nietzsche, the awful [das Schreckliche]: a blind power and force, a barbaric principle, that can be overcome but never eliminated and which is 'the foundation of all greatness and beauty'."11 James' close friend and colleague, Charles Sanders Peirce, informed him a letter that his own philosophy had been most deeply influenced by Schelling. "If you were to call my own philosophy Schellingianism transformed in the light of modern physics, I should not take it hard." ${ }^{12}$

It was in this sense that Schelling maintained that there is no health or sickness per se (as if these were discrete entities) any more so than there is Good or Evil per se. Health becomes thinkable as what has been lost in sickness, the lost origin concealed within the ataxia of forces that is sickness. "Therefore each Wesen can only become revealed in its opposite, love only in hate, unity only in strife" (I/7, 373). In this sense, sickness would be the inversion of health within health itself. It is not a moving away from health, but rather an ataxia within health that turns health against itself. The soul of sickness, the opposite force (the ideal and incomprehensible force) concealed within the ataxia of sickness, is health, in the same way that Schelling claimed that "the soul of all hate is love" (I/7, 401). Health is the indivisible remainder of sickness, the unthinkable soul within sickness, just as love is topsy-turvy hate and hate is perverse love.

Evil, the moral equivalent of sickness, refuses the general economy of forces and demands itself. "What causes illness other than a churlishness towards development, other than the individual strength not wanting to continue with the whole, not wanting to die away with the whole, but obstinately wanting to be for itself" (C, 36).

The model of sickness that operates in Schelling's philosophy is similar to the model that Georges Canguilhem articulates in The Normal and the Pathological (1943). ${ }^{13}$ Sickness has traditionally been construed in one of two ways. Either one first has health and endeavors to defend it against the barbarism of illness - "Disease enters and leaves man as through a door" (NP, 39) - or, as did the Greeks, one assumes that pathology indicates that the body is out of balance and must be returned to its equilibrium (NP, 40). Both approaches assume that the pathological opposes the normal just as sickness opposes health. Both accounts presuppose that we know what it means to be healthy, that there is some idea that adequately circumscribes the body's flourishing. For Canguilhem one does not begin knowing what it means to be healthy and hence assume that healing is the war against the looming threat

${ }^{11}$ Karl Löwith, Nietzsches Philosophie der ewigen Wiederkehr des Gleichen (1935), fourth proofed edition based on the corrected third edition, (Hamburg: Felix Meiner, 1986), 154.

12 Quoted in R. B. Perry, The Thought and Character of William James (Boston: Little Brown, 1935), II: 416. See also Bruce Matthews' introduction to his translation of Schelling's inaugural Berlin lectures, The Grounding of Positive Philosophy (Albany: State University of New York Press, 2007), 7475.

13 Georges Canguilhem, The Normal and the Pathological, trans. Carolyn Fawcett and Robert Cohen (New York: Zone Books, 1989). Henceforth NP. 
of sickness. One does not first have health. Health is not a discernible set of functions. A healthy person is not someone who meets the formal criteria for being in good working order. We are first fallen from health, always thinking it in arrears, and hence pathology is not anti-life, but rather "another way of life" (NP, 89). "Diseases are new ways of life" (NP, 100) that a posteriori reveal more of the body's heretofore inhibited possibilities. "Disease reveals normal functions to us at the precise moment when it deprives us of their exercise" (NP, 101). Nietzsche himself in a Nachlaß fragment claimed that "health and sickness are not essentially different things, like the old doctors and a few practitioners still believe today" (III, 781).

Hans Georg Gadamer, who mounted towards the end of his life one of the great defenses of the art of healing, of the Heilmittel, called the revelatory movement of sickness, that is to say, that health continually announces itself by what it is not, and therefore as something always still to come, as a site futurity and natality, die Verborgenheit der Gesundheit, the mysterious hiddeness of health.

Without doubt it is part of our nature as living beings that our conscious selfawareness remains largely in the background so that our enjoyment of good health is constantly concealed from us. Yet despite its hidden character health none the less manifests itself in a general feeling of well-being. It shows itself above all where such a feeling of well-being means that we are open to new things, ready to embark on new enterprises and, forgetful of ourselves, scarcely notice the demands and strains which are put on us. This is what health is. It does not consist in an increasing concern for every fluctuation in one's general physical condition or the eager consumption of prophylactic medicines. ${ }^{14}$

One can already hear the anticipation of the mysterious hiddeness of the great health and its transformative emergence:

It may come gradually, or it may occur abruptly; it may come through altered feelings, or through altered powers of action; or it may come through new intellectual insights, or through [mystical] experiences ... However it come, it brings a characteristic sort of relief; . . . it often transforms the most intolerable misery into the profoundest and most enduring happiness. (VR, 195)

Finally, in what radical, post-doctrinal sense can a saint be Nietzschean and can Nietzsche be in some delicate and unexpected way, saintly? ${ }^{15}$ This depends, I think, on how we understand the health of philosophy itself.

${ }^{14}$ Hans-Georg Gadamer, "On the Enigmatic Character of Health", The Enigma of Health, trans. Jason Gaiger and Nicholas Walker (Stanford, California: Stanford University Press: 1996), 112.

15 As Gianni Vattimo has recently argued: "Yet this is the main paradox of Nietzsche's philosophy: his announcement of the death of God, really the announcement of the end of all metanarratives, does not preclude the possibility that many gods might be born. Perhaps we have not meditated sufficiently on the explicit assertion by Nietzsche that 'it is the moral God who is denied', that is, God as ground, the pure act in Aristotle, the supreme watchmaker and architect of the universe in 
Enlightenment rationalism." After Christianity, trans. Luca D'Isanto (New York: Columbia University Press, 2002), 86-87. 